\title{
The Inhibition of Uric Acid Formation Catalyzed by Xanthine Oxidase Properties of the Alkyl Caffeates and Cardol
}

\author{
Noriyoshi Masuoka ${ }^{1}$, Ken-ichi Nihei ${ }^{2}$, Takayoshi Masuoka ${ }^{2}$, Kouhei Kuroda ${ }^{1}, K$ Keni Sasaki ${ }^{3}$ \\ \& Isao Kubo ${ }^{2}$ \\ ${ }^{1}$ Department of Life Science, Okayama University of Science, Okayama, Japan \\ ${ }^{2}$ Department of Environmental Science, Policy and Management, University of California, Berkeley, California, \\ USA \\ ${ }^{3}$ Department of Pharmaceutical Science, Okayama University, Okayama, Japan \\ Correspondence: Noriyoshi Masuoka, Department of Life Science, Okayama University of Science, 1-1 \\ Ridai-cho, Kita-ku, Okayama 700-0005, Japan. Tel: 81-86-256-9593. E-mail: masuokan@dls.ous.ac.jp
}

Received: June 27, 2012 Accepted: July 10, 2012 Online Published: July 24, 2012

doi:10.5539/jfr.v1n3p257 URL: http://dx.doi.org/10.5539/jfr.v1n3p257

\begin{abstract}
Xanthine oxidase inhibitors may serve as therapeutic agents for hyperuricaemia and/or oxidative stress. From our continuing investigation, we proposed that some inhibitors for reactions catalyzed by xanthine oxidase consisted of a head portion and a tail portion and that each portion had different functions for inhibition. In a previous study on the effect of alkyl gallates on the uric acid formation catalyzed by xanthine oxidase it was shown that the alkyl chain length needs to be longer than $\mathrm{C}_{6}$ to exert inhibitory activity. In the current study, compounds having different head portions, alkyl caffeates, alkyl protocatechuates, alkyl 3,5-dihydroxybenzoates, 3,4dihydroxyphenylalkanoates and 3,5-dihydroxyphenylalkanoates were prepared, and their effects on the uric acid formation were examined. A series of alkyl caffeates $\left(\mathrm{C}_{1}-\mathrm{C}_{10}\right)$ was demonstrated effective in inhibiting the uric acid formation, and the inhibitory activity increased by increasing the alkyl chain length. However, none of the other compounds was effective in inhibiting the uric acid formation. These results indicate that head portions in these compounds are important for the inhibition of uric acid formation and require further a specific structural feature to elicit the inhibitory activity.
\end{abstract}

Keywords: xanthine oxidase inhibition, uric acid formation, alkyl caffeates, cardol, alkyl protocatechuates, alkyl 3,5-dihydroxybenzoates

\section{Introduction}

Xanthine oxidase (EC 1.1.3.22), a molybdenum-containing enzyme, catalyzes the oxidation of hypoxanthine to xanthine and ultimately to uric acid. The accumulation of uric acid leads to hyperuricaemia and gout (Hatano et al., 1990; Nakanishi et al., 1990), so xanthine oxidase inhibitors may serve as therapeutic agents for hyperuricaemia and/or gout. Xanthine oxidase also generates superoxide anion, and an excess of superoxide anion generation leads to peroxidative damage in cells (Fong, McCay, Poyer, Keele \& Misra, 1973). So, xanthine oxidase inhibitors are also useful to prevent postischemic injury (McCord, 1985). In our continuing investigation of xanthine oxidase inhibitors, it has become evident that the balance of hydrophilic and hydrophobic moieties of

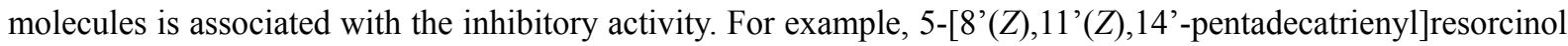
(1), isolated from the cashew Anacardium occidentale (Anacardiaceae), commonly known as cardol $\left(\mathrm{C}_{15: 3}\right)$, inhibits the generation of the superoxide anion catalyzed by xanthine oxidase, while its parent compound, resorcinol (2), does not. A similar observation was noted between 5-alk (en) ylresorcinols referred to as cardols and their parent compound, resorcinol, against tyrosinase (EC 1.14.18.1) (Kubo, Kinst-Hori \& Yokokawa, 1994). These results suggest that the alk (en) yl side chain length in cardol is related to the activity. In the xanthine oxidase molecule, the active sites of uric acid formation and superoxide anion generation are different. That is, an inhibitor which binds the xanthine binding site in xanthine oxidase inhibits the uric acid formation by xanthine oxidase. In the case of $6-\left[8^{\prime}(Z), 11^{\prime}(Z), 14^{\prime}\right.$-pentadecatrienyl]salicylic acid, commonly known as anacardic acid $\left(\mathrm{C}_{15: 3}\right)$ (3), it binds to xanthine oxidase and cooperatively inhibits uric acid formation $\left(\mathrm{IC}_{50}=162 \pm 10 \mu \mathrm{M}, \mathrm{n}=1.7 \pm 0.2\right)$ but its parent compound, salicylic acid (4), does not possess this inhibitory activity. The hydrophobic pentadecatrienyl chain, the tail portion of the inhibitors, is associated with 
hydrophobic binding to the enzyme. To confirm this function, we synthesized a homologous series of alkyl gallates having different alkyl chain lengths and examined them. The longer hydrophobic alkyl chain $\left(>\mathrm{C}_{6}\right)$ of the alkyl gallates, for example, octyl gallate (5), interacted with the hydrophobic region near the xanthine binding site in the enzyme and induced binding. However, superoxide anion generation with xanthine oxidase is equally inhibited by gallic acid (6) and all of the alkyl gallates, and this inhibition is not associated with the alkyl chain length. This suggested that the inhibition of superoxide anion generation was caused by the binding of the inhibitor to the FAD binding site followed by a reduction of the enzyme molecule with the pyrogallol moiety, the head portion of the alkyl gallates (Masuoka \& Kubo, 2004; Masuoka, Nihei, \& Kubo, 2006).

In the current study, we examined the effect of different head portions in inhibitors on uric acid formation catalyzed by xanthine oxidase, since the role of the hydrophilic head portion of the inhibitors is still so poorly understood. The inhibition of the uric acid formation catalyzed by xanthine oxidase using compounds having some different head portions was examined. The structures of these compounds are shown in Figure 1.

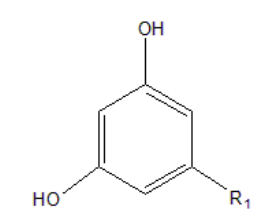

(1) Cardol $\left(\mathrm{C}_{15: 3}\right) \quad \mathrm{R}_{1}=\mathrm{C}_{15} \mathrm{H}_{25}$

(2) Resorcinol $\quad \mathrm{R}_{1}=\mathrm{H}$

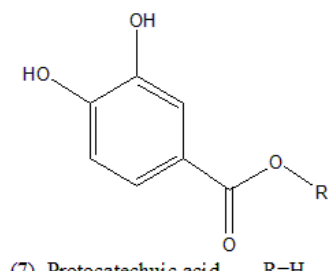

(8) Propyl protocatechuate $\mathrm{R}=\mathrm{C}_{3} \mathrm{H}_{7}$

(9) Octyl protocatechuate $\mathrm{R}=\mathrm{C}_{8} \mathrm{H}_{17}$<smiles>[R]OC(=O)/C=C/c1ccc(O)c(O)c1</smiles>

$$
\begin{array}{ll}
\text { (13) Caffeic acid } & \mathrm{R}=\mathrm{H} \\
\text { (14) Methylcaffeate } & \mathrm{R}=\mathrm{CH}_{3} \\
\text { (15) Propylcaffeate } & \mathrm{R}=\mathrm{C}_{3} \mathrm{H}_{7} \\
\text { (16) Butylcaffeate } & \mathrm{R}=\mathrm{C}_{4} \mathrm{H}_{9} \\
\text { (17) Pentylcaffeate } & \mathrm{R}=\mathrm{C}_{5} \mathrm{H}_{11} \\
\text { (18) Hexylcaffeate } & \mathrm{R}=\mathrm{C}_{6} \mathrm{H}_{13} \\
\text { (19) Heptylcaffeate } & \mathrm{R}=\mathrm{C}_{7} \mathrm{H}_{15} \\
\text { (20) Decylcaffeate } & \mathrm{R}=\mathrm{C}_{10} \mathrm{H}_{21} \\
\text { (21) Phenethyl caffeate } & \mathrm{R}=\mathrm{CH}_{2} \mathrm{CH}_{2} \mathrm{C}_{6} \mathrm{H}_{5}
\end{array}
$$<smiles>O=C(O)c1c(O)cccc1Br</smiles>

(3) Anacardic acid ( $\left.\mathrm{C}_{15: 3}\right) \mathrm{R}=\mathrm{C}_{15} \mathrm{H}_{25}$ (4) Salicylic acid $\quad \mathrm{R}=\mathrm{H}$<smiles>[R]C(=O)Oc1ccc(O)c(O)c1</smiles>

(10) 3,4-Dihydroxyphenyloctanoate $\quad \mathrm{R}=\mathrm{C}_{7} \mathrm{H}_{15}$ (11) 3,4-Dihydroxyphenyldodecanoate $\mathrm{R}=\mathrm{C}_{11} \mathrm{H}_{23}$<smiles>[R]OC(=O)c1cc(O)cc(O)c1</smiles>

(22) 3,5-Dihydroxybenz oic acid $\quad \mathrm{R}=\mathrm{H}$ (23) Hexyl 3,5-dihydroxybenzoate $\quad \mathrm{R}=\mathrm{C}_{6} \mathrm{H}_{13}$ (24) Dodecyl 3,5-dihydroxybenzoate $\mathrm{R}=\mathrm{C}_{12} \mathrm{H}_{25}$<smiles>[R]c1cccc(O)c1</smiles>

(27) Cardanol $\left(\mathrm{C}_{15: 3}\right) \mathrm{R}_{1}=\mathrm{C}_{15} \mathrm{H}_{25}$<smiles>COC(=O)c1cc(O)c(O)c(O)c1</smiles>

(5) Octyl gallate $\mathrm{R}=\mathrm{C}_{8} \mathrm{H}_{17}$

(6) Gallic acid $\mathrm{R}=\mathrm{H}$<smiles>[R]OC(=O)/C=C/c1ccc(O)cc1</smiles>

(12) Methyl coumarate $\mathrm{R}=\mathrm{CH}_{3}$<smiles>[R]C(=O)Oc1cc(O)cc(O)c1</smiles>

(25) 3,5-ihydroxyphenylheptanoate $\mathrm{R}=\mathrm{C}_{6} \mathrm{H}_{13}$ (26) 3,5-ihydroxyphenyltridecanoate $\mathrm{R}=\mathrm{C}_{12} \mathrm{H}_{25}$

Figure 1. Chemical structures of compounds having different head portions

\section{Materials and Methods}

\subsection{Chemicals}

The cardol $\left(\mathrm{C}_{15: 3}\right)$ used in this experiment was available from our previous work (Kubo, Komatsu \& Ochi, 1986). Caffeic acid, protocatechuic acid, 3,5-dihydroxybenzoic acid, 1,3,4-trihydroxy-benzene, 1,3,5-trihydroxybenzene and xanthine were purchased from Aldrich Chemical Co. (Milwaukee, WI) and Sigma Chemical Co. (St. Louis, MO). The series of alkyl $\left(C_{3}-C_{12}\right)$ protocatechuates and alkyl $\left(C_{1}-C_{10}\right)$ caffeates were synthesized by one step 
esterification utilizing DCC, as previously reported (Nihei, Nihei, \& Kubo, 2003). The ${ }^{1} \mathrm{H}$ NMR (500 MHz) data for a typical compound, propyl caffeate, in $\mathrm{CDCl}_{3}$ are as follows; $\delta 7.59(1 \mathrm{H}, \mathrm{d}, J=15.9 \mathrm{~Hz}), 7.12(1 \mathrm{H}, \mathrm{d}, J=$ $1.8 \mathrm{~Hz}), 7.00(1 \mathrm{H}, \mathrm{dd}, J=8.2,1.8 \mathrm{~Hz}), 6.88(1 \mathrm{H}, \mathrm{d}, J=8.2 \mathrm{~Hz}), 6.27(1 \mathrm{H}, \mathrm{d}, J=15.9 \mathrm{~Hz}), 4.17(2 \mathrm{H}, \mathrm{t}, J=6.7$ $\mathrm{Hz}), 1.73(2 \mathrm{H}, \mathrm{sex}, J=6.7 \mathrm{~Hz}), 0.99(3 \mathrm{H}, \mathrm{t}, J=6.7 \mathrm{~Hz})$.

The synthesis of 3,4-dihydroxyphenylalkanoates $\left(\mathrm{C}_{8}-\mathrm{C}_{12}\right)$ was also achieved by one step esterification using DCC. The ${ }^{1} \mathrm{H}$ NMR (500 MHz) data for a typical compound, 3,4-dihydroxyphenylheptanoate, in $\mathrm{CDCl}_{3}$ are as follows; $\delta 6.90(1 \mathrm{H}, \mathrm{d}, J=8.4 \mathrm{~Hz}), 6.44(1 \mathrm{H}, \mathrm{d}, J=2.7 \mathrm{~Hz}), 6.38(1 \mathrm{H}, \mathrm{dd}, J=8.4,2.7 \mathrm{~Hz}), 5.63(1 \mathrm{H}, \mathrm{bs}), 5.19$ $(1 \mathrm{H}, \mathrm{bs}), 2.58(2 \mathrm{H}, \mathrm{t}, J=7.3 \mathrm{~Hz}), 1.75(2 \mathrm{H}$, quin, $J=7.3 \mathrm{~Hz}), 1.40(2 \mathrm{H}, \mathrm{m}), 1.26(4 \mathrm{H}, \mathrm{m}), 0.88(3 \mathrm{H}, \mathrm{t}, J=6.4$ $\mathrm{Hz})$. Likewise, 3,5-dihydroxyphenylalkanoates $\left(\mathrm{C}_{7}-\mathrm{C}_{13}\right)$ were prepared via one step esterification utilizing DCC. The ${ }^{1} \mathrm{H}$ NMR (500 MHz) data for a typical compound, 3,5-dihydroxyphenyloctanoate, in $\mathrm{CDCl}_{3}$ are as follows; $\delta$ $6.10(3 \mathrm{H}, \mathrm{s}), 2.54(2 \mathrm{H}, \mathrm{t}, J=7.5 \mathrm{~Hz}), 1.73(2 \mathrm{H}$, quint, $J=7.5 \mathrm{~Hz}), 1.32(8 \mathrm{H}, \mathrm{m}), 0.89(3 \mathrm{H}, \mathrm{t}, J=6.7 \mathrm{~Hz})$. Alkyl $\left(\mathrm{C}_{6}-\mathrm{C}_{12}\right)$ 3,5-dihydroxybenzoates were synthesized from 3,5-dibenzyloxybenzoic acid and alcohol by the Mitsunobu reaction followed by hydrogenolysis, as previously reported (Nihei et al., 2003).

\subsection{Sample Solution}

Compounds were dissolved with DMSO, and for each a $10 \mathrm{mM}$ solution was prepared.

\subsection{Assay of Inhibitory Activity of Uric Acid Formation Generated by Xanthine Oxidase}

The reaction mixture consisted of $2.76 \mathrm{~mL}$ of $40 \mathrm{mM}$ sodium carbonate buffer containing $0.1 \mathrm{mM}$ EDTA (pH 10.0), $0.06 \mathrm{~mL}$ of $10 \mathrm{mM}$ xanthine and $0.06 \mathrm{~mL}$ of sample solution, and was maintained at $25^{\circ} \mathrm{C}$. The reaction was started by the addition of $0.12 \mathrm{~mL}$ of xanthine oxidase $(0.04$ Unit), and the absorbance at $293 \mathrm{~nm}$ was recorded for $60 \mathrm{~s}$. A control experiment was carried out with DMSO as the sample solution. The reaction rate was calculated from the proportional increase of absorbance.

\subsection{Assay and Data Analysis}

Each assay was performed in triplicate in separate experiments, and the assay was performed with Sigma plot 2001 (SPSS Inc., Chicago, IL). The inhibition mode and kinetic parameters were analyzed with Enzyme Kinetics Module 1.1(SPSS Inc.) equipped with Sigma Plot 2001.

\section{Results}

\subsection{Inhibitory Activity of Alkyl Protocatechuates and 3,4-Dihydroxyphenylalkanoates}

The effects of the synthesized alkyl protocatechuates $(\mathbf{8}, \mathbf{9})$ and 3,4-dihydroxyphenylalkanoates $(\mathbf{1 0 , 1 1 )}$ on uric acid formation catalyzed by xanthine oxidase were examined, and these compounds having a 3 , 4-dihydroxybenzene portion exhibited weak inhibitory activity. The inhibitory activity was increased with increases in the alkyl chain length. The data are summarized in Table 1. However, the data on the alkyl protocatechuates having more than a $\mathrm{C}_{8}$ alkyl chain length is unclear due to solubility limitations in the water-based test solution.

Table 1. Inhibition of uric acid formation by compounds having a 3,4-dihydroxybenzene portion. Superscript a indicates $125 \mu \mathrm{M}$, and $\mathrm{b}$ indicates $200 \mu \mathrm{M}$

\begin{tabular}{lc}
\hline \multicolumn{2}{c}{ Compounds tested } \\
\hline Protocatechuic acid (7) & No inhibition $^{\mathrm{a}}$ \\
Propyl protocatechuate (8) & No inhibition $^{\mathrm{a}}$ \\
Octyl protocatechuate (9) & $22 \%$ inhibition $^{\mathrm{a}}$ \\
3,4-Dihydroxyphenyloctanoate (10) & $7 \%$ inhibition $^{\mathrm{b}}$ \\
3,4-Dihydroxyphenyldodecanoate (11) & $27 \%$ inhibition $^{\mathrm{b}}$ \\
\hline
\end{tabular}

\subsection{Inhibitory Activity of Alkyl Caffeates and Related Compounds}

Methyl coumarate (12, methyl 4-hydroxycinnamate), caffeic acid (13) and alkyl caffeates (14 - 20) were also examined. Methyl coumarates and caffeic acid did not affect uric acid formation, but alkyl $\left(\mathrm{C}_{1}-\mathrm{C}_{10}\right)$ caffeates exhibited competitive inhibition activity. This shows that the inhibition by alkyl caffeates increased with an increasing the chain length. As we previously reported for alkyl gallates (Masuoka et al., 2006), the alkyl chain length of alkyl caffeates $\left(\mathrm{C}_{1}-\mathrm{C}_{10}\right)$ plays an important role in the inhibitory activity. Lineweaver-Burk plots of 
uric acid formation in the presence of propyl caffeate (15) are shown in Figure 2. Although alkyl protocatechuates, 3,4-dihydroxyphenylalkanoates and alkyl caffeates all have a common catechol moiety (3,4-dihydroxybenzene) and alkyl side chains, the alkyl caffeates have distinctly more potent inhibitory activity.

Table 2. Inhibition by methyl 4-hydroxycinnamate, caffeic acid and alkyl caffeates. Superscript a indicates 200 $\mu \mathrm{M}$

\begin{tabular}{lccc}
\hline Compounds tested & $\mathrm{IC}_{50}(\mu \mathrm{M})$ & $\mathrm{K}_{\mathrm{I}}(\mu \mathrm{M})$ & Type \\
\hline Methyl 4-hydroxycinnamate (12) & No inhibition $^{\mathrm{a}}$ & - & - \\
Caffeic acid (13) & No inhibition $^{\mathrm{a}}$ & - & - \\
Methyl caffeate (14) & $143 \pm 13$ & $38.6 \pm 0.5$ & Competitive \\
Propyl caffeate (15) & $30.2 \pm 2.1$ & $7.8 \pm 0.8$ & Competitive \\
Butyl caffeate (16) & $26.5 \pm 2.0$ & $7.3 \pm 0.5$ & Competitive \\
Pentyl caffeate (17) & $18.0 \pm 0.9$ & $4.3 \pm 0.4$ & Competitive \\
Hexyl caffeate (18) & $19.0 \pm 1.0$ & $3.6 \pm 0.6$ & Competitive \\
Heptyl caffeate (19) & $12.5 \pm 0.5$ & $3.5 \pm 0.5$ & Competitive \\
Decyl caffeate (20) & $10.0 \pm 1.0$ & $3.3 \pm 0.5$ & Competitive \\
\hline
\end{tabular}

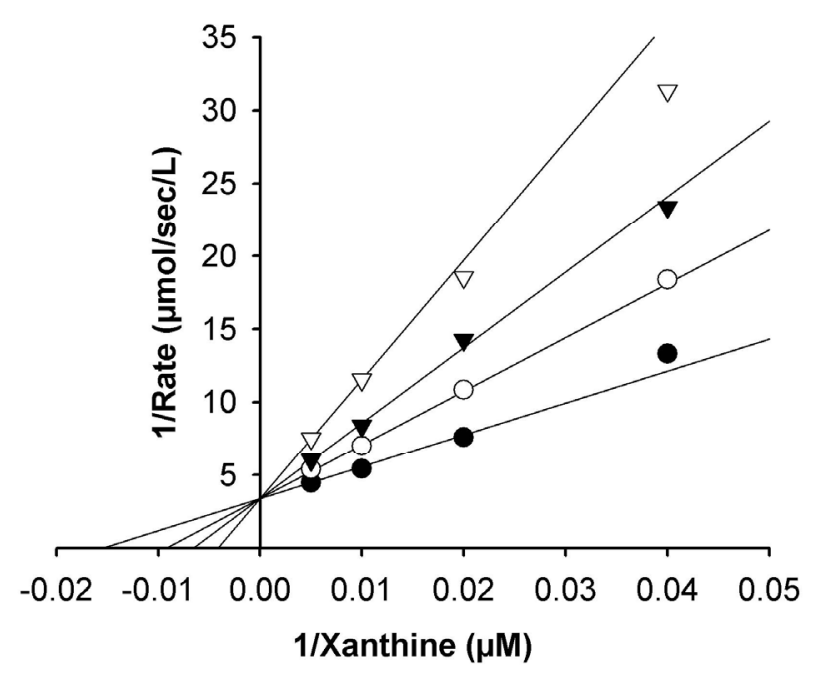

Figure 2. Lineweaver -Burk plot of uric acid formation by xanthine oxidase in the presence of propyl caffeate (15). $\bullet, 0.0 \mu \mathrm{M} ; \circ, 5 \mu \mathrm{M} ; \nabla, 10 \mu \mathrm{M} ; \nabla, 20 \mu \mathrm{M}$ propyl caffeate

\subsection{Inhibitory Activity of Cardol and Related Compounds}

Cardol $\left(\mathrm{C}_{15: 3}\right)$ (1), 3,5-dihydroxybenzoates (22 - 24) and 3,5-dihydroxyphenylalkanoates $\mathbf{( 2 5 , 2 6 )}$ having the same aromatic ring (3,5-dihydroxybenzene) and similar alkyl side chain lengths were examined. The summarized results are shown in Table 3. Cardol did not inhibit uric acid formation up to $400 \mu \mathrm{M}$, but, after preincubation for $3 \mathrm{~min}$, a weak inhibitory activity was observed. Alkyl 3,5-dihydroxybenzoates and 3,5-dihydroxyphenylalkanoates hardly inhibited uric acid formation at all. 
Table 3. Inhibition by cardol and related compounds. Superscript a indicates that cardol $\left(\mathrm{C}_{15: 3}\right)$ exhibited a week inhibition after preincubation for $3 \mathrm{~min}$, and the $\mathrm{IC}_{50}$ was $430 \pm 45 \mu \mathrm{M}\left(\mathrm{K}_{\mathrm{I}}=\mathrm{K}_{\mathrm{IS}}=370 \pm 30 \mu \mathrm{M}\right)$. In comparison, cardanol $\left(\mathrm{C}_{15: 3}\right)$ exhibited a $25 \pm 2 \%$ inhibition at $200 \mu \mathrm{M}$

\begin{tabular}{lc}
\hline Compounds tested & At $200 \mu \mathrm{M}$ \\
\hline Resorcinol (2) & No inhibition \\
Cardol $\left(\mathrm{C}_{15: 3}\right)^{\mathrm{a}}(1)$ & No inhibition \\
3,5-Dihydroxybenzoic acid (22) & No inhibition \\
Hexyl 3,5-dihydroxybenzoate (23) & No inhibition \\
Dodecyl 3,5-dihydroxybenzoate (24) & No inhibition \\
3,5-Dihydroxyphenylheptanoate (25) & $10 \%$ inhibition \\
3,5-Dihydroxyphenyltridecanoate (26) & $21 \%$ inhibition \\
\hline
\end{tabular}

\section{Discussion}

The xanthine oxidase-catalyzed reaction is known to proceed via transfer of an oxygen atom to xanthine from the molybdenum center. X-ray crystallographic analysis of bovine milk xanthine oxidase indicated that one can model the binding of bicyclic substrates, e.g. with Phe 1009 perpendicular to the six-membered ring of xanthine and Phe 914 stacked flat on top of the substrate's five-membered ring, which is then able to form a covalent bond with one of the molybdenum ligands (Enroth et al., 2000). In terms of the inhibitory effect of the head portion in compounds on the activity, we found that anacardic acid $\left(\mathrm{C}_{15: 3}\right)(3)$, which has a salicylic acid moiety as the head portion, inhibited uric acid formation, but cardanol $\left(\mathrm{C}_{15: 3}\right)(\mathbf{2 7})$, having a 3-hydroxybenzene moiety, did not (Masuoka \& Kubo, 2004).

To study the effect of the head portion in the compounds on their activity, the effect of alkyl protocatechuates and 3,4-dihydroxyphenylalkanoates were examined (Table 1). Alkyl gallates having more than $\mathrm{a}_{6}$ chain length were inhibitory (Masuoka et al., 2006), but alkyl protocatechuates and 3,4-dihydroxyphenyl alkanoates exhibited only a very low inhibitory effect. This shows that a difference in the aromatic ring $(3,4,5$-trihydroxybenzoyl and 3, 4-dihydroxybenzoyl) portions in the inhibitors affected the inhibition of uric acid formation and suggested that the latter hardly bound the xanthine binding site in xanthine oxidase.

To confirm the effect of the compound head portion on the activity, the effect of methyl coumarate (12) and methyl caffeate (13) was examined. Methyl coumarate did not display any inhibitory effect for uric acid formation but methyl caffeate did (Table 2). This result clearly indicated that the head (aromatic ring) portions are important for the inhibition of uric acid formation.

It was observed that there is a substantial difference in the inhibitory activity of alkyl caffeates and alkyl protocatechuates, or 3,4-dihydroxyphenylalkanoates. The inhibitory effect of alkyl caffeates was higher than that of the alkyl protocatechuates and 3,4-dihydroxyphenylalkanoates, even though these compounds have a same head portion and similar alkyl chains. The only difference between them is the positon of the ester bond. This suggests that alkyl caffeates having a propionate ester in the connective portion between tail and head portions have a higher affinity to the xanthine binding site than compounds having benzoyl or benzoxy ester in the connective portion. As Wang et al. (2009) previously reported that the interaction between the tail portion of phenethyl caffeate (21) and the hydrophobic area near the xanthine binding site in xanthine oxidase is considerable, in addition to the head and tail structures, we deduced that the position of the ester group in the connective portion between the tail and head portions is another important property for the binding to the xanthine binding site in xanthine oxidase.

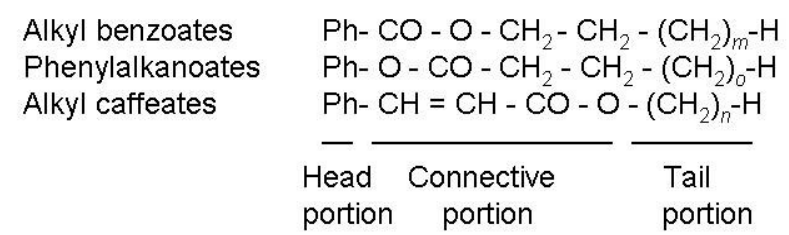

To understand antioxidant activity of cardol $\left(\mathrm{C}_{15: 3}\right)(\mathbf{1})$, we examined cardol, 3,5-dihydroxybenzoates (22 - 24) and 3,5-dihydroxyphenylalkanoates $(\mathbf{2 5}, \mathbf{2 6})$. Cardol displayed an inhibition $\left(\mathrm{IC}_{50}=115 \pm 10 \mu \mathrm{M}, \mathrm{n}=5.2 \pm 0.2\right)$ of 
superoxide anion generation but a weak inhibition of uric acid formation, after preincubation for $3 \mathrm{~min}$ (Table 3 ). Cardol $\left(\mathrm{C}_{15: 3}\right)$, alkyl 3,5-dihydroxybenzoates and 3,5-dihydroxyphenylalkanoates all scarcely inhibit uric acid formation. As these compounds, which have the same aromatic ring (3,5-dihydroxybenzene) and alkyl side chain lengths, hardly bind to the xanthine binding site in xanthine oxidase, we confirmed again that difference in the aromatic ring portions in the compounds is important for the inhibition of uric acid formation. It was also deduced that the antioxidant activity of cardol $\left(\mathrm{C}_{15: 3}\right)$ was due to a binding to the superoxide generation (FAD), not to binding to the uric acid formation site or a reduction of xanthine oxidase. This suggested that cardol $\left(\mathrm{C}_{15: 3}\right)$ is a specific inhibitor for superoxide anion generation catalyzed by xanthine oxidase. Further study is currently in progress.

\section{References}

Enroth, C., Eger, B. T., Okamoto, K., Nishino, T., Nishino, T., \& Pai, E. F. (2000). Crystal structures of bovine milk xanthine dehydrogenase and xanthine oxidase: Structure-based mechanism of conversion. Proc. Nat. Acad. Sci., 97, 10723-10728. http://dx.doi.org/10.1073/pnas.97.20.10723

Fong, K. L., McCay, P. B., Poyer, J. L., Keele, B. B., \& Misra, H. (1973). Evidence that peroxidation of lysosomal membranes is initiated by hydroxyl free radicals produced during flavin enzyme activity. J. Biol. Chem., 248, 7792-7797.

Hatano, T., Yasuhara, T., Yoshihara, R., Agata, J., Noro, T., \& Okuda, T. (1990). Effects of interaction of tannins with co-existing substances. VII. Inhibitory effects of tannins and related polyphenols on xanthine oxidase. Chem. Pharm. Bull., 38, 1224-1229. http://dx.doi.org/10.1248/cpb.38.1224

Kubo, I., Kinst-Hori, I., \& Yokokawa, Y. (1994). Tyrosinase inhibitors from Anacardium occidentale fruits. J. Nat. Prod., 57, 545-552. http://dx.doi.org/10.1021/np50106a021

Kubo, I., Komatsu, S., \& Ochi, M. (1986). Molluscicides from the cashew Anacardium occidentale and their large-scale isolation. J. Agri. Food Chem., 34, 970-973. http://dx.doi.org/10.1021/jf00072a010

Masuoka, N., \& Kubo, I. (2004). Characterization of Xanthine oxidase inhibition by anacardic acids. Biochim. Biophys. Acta, 1688, 245-249. http://dx.doi.org/10.1016/j.bbadis.2003. 12.010

Masuoka, N., Nihei, K., \& Kubo, I. (2006). Xanthine oxidase inhibitory activity of alkyl gallates. Mol. Nutr. Food Res., 50, 725-731. http://dx.doi.org/10.1002/mnfr.200500250

McCord, J. M. (1985). Oxygen-derived free radicals in postischemic tissue injury. N. Eng. J. Med., 312, 159-163. http://dx.doi.org/10.1056/NEJM198501173120305

Nakanishi, T., Nishi, M., Inada, A., Obata, H., Tanabe, N., Abe, S., \& Wakashiro, M. (1990). Two potent inhibitors of xanthine oxidase from leaves of Perilla frutescens Britton var. acuta Kodo. Chem. Pharm. Bull., 38, 1772-1774. http://dx.doi.org/10.1248/cpb.38.1772

Nihei, K., Nihei, A., \& Kubo, I. (2003). Rational design of antimicrobial agents: antifungal activity of alk(en)yl dihydroxybenzoates and dihydroxyphenyl alkanoates. Bioorg. Med. Chem. Lett., 13, 3993-3996. http://dx.doi.org/10.1016/j.bmcl.2003.08.057

Wang, S. H., Chen, C. S., Huang, S. H., Yu, S. H., Lai, Z. Y., Huang, S. T., \& Lin, C. M. (2009). Hydrophilic ester-bearing chlorogenic acid binds to novel domain to inhibit xanthine oxidase. Planta Med., 75, 1237-1240. http://dx.doi.org/10.1055/s-0029-1185521 